\title{
Genetic variation among quince (Cydonia oblonga Mill.) genotypes sampled from the Coruh valley in Turkey
}

\author{
E. Orhan 1 , G. Nardemir ${ }^{2}$, G. Agar ${ }^{2}$ and S. Ercisli ${ }^{3}$ \\ ${ }^{1}$ Department of Agricultural Biotechnology, Faculty of Agriculture, \\ Erzurum, Turkey \\ ${ }^{2}$ Department of Biology, Faculty of Sciences, Ataturk University, \\ Erzurum, Turkey \\ ${ }^{3}$ Department of Horticulture, Faculty of Agriculture, Erzurum, Turkey \\ Corresponding author: S. Ercisli \\ E-mail: sercisli@gmail.com \\ Genet. Mol. Res. 13 (1): 445-449 (2014) \\ Received August 15, 2013 \\ Accepted October 18, 2013 \\ Published January 21, 2014 \\ DOI http://dx.doi.org/10.4238/2014.January.21.12
}

\begin{abstract}
Turkey has very rich quince genetic resources, and the country currently dominates world quince production. In particular, the northeastern part of the country has notable Cydonia oblonga Mill. germplasm. Authenticating the identity of germplasm resources of $C$. oblonga Mill. would be of great value for breeding practices. In the present study, genetic variations of 14 C. oblonga Mill. genotypes sampled from the Coruh valley of Turkey were investigated. Ten random primers generated 53 DNA markers. The highest polymorphism ratio was observed in the OPA07 primer (86\%), while the lowest was observed in OPA03 (29\%). The percentage of polymorphic bands was $51 \%$, which demonstrated the efficiency of the primers used. The similarity matrix revealed that the similarity among genotypes ranged between 0.42 and 0.96. The identified random amplified polymorphic DNA markers enabled clear discrimination among all genotypes considered.
\end{abstract}

Key words: Quince; Cydonia oblonga Mill.; RAPD; Genetic diversity 


\section{INTRODUCTION}

Intensive agriculture has resulted in the loss of much of the genetic diversity possessed by local and historical genotypes. New varieties developed through modern breeding techniques are becoming increasingly genetically homogenous than ever before, and are thus more vulnerable to pathogen infection and adverse environmental conditions (Asins and Carbonell, 1989). This has prompted scientists to look for new sources of variations to broaden the genetic background of highly resistant genotypes, which can be more adaptable to local environmental fluctuations. Local genotypes found within the same agro-climatic conditions offer the advantage of being utilized more easily for breeding purposes relative to those found in more distant environments. Thus, precious genetic resources of local genotypes should be conserved for proper utilization in breeding practices. In order to achieve this, it is imperative to assess the genetic variability currently present among local genotypes (Ercisli, 2004; Kafkas et al., 2008).

The quince (Cydonia oblonga Miller) belongs to the genus Cydonia, and is native to warm-temperate regions, including Asia Minor (Browicz, 1972). The total global quince production is approximately 540,000 tons, and Turkey currently ranks first in terms of production, contributing 120,000 tons $(22 \%)$ to the global total. The other important producer countries are China (110,000 tons), Uzbekhistan (67,000 tons), Morocco (45,000 tons), Iran (38,000 tons), Argentina (27,000 tons), and Azerbaijan (23,000 tons) (FAO, 2010).

Quince is a small deciduous tree, growing 5-8 $\mathrm{m}$ tall and 4-6 $\mathrm{m}$ wide. Quince is related to apples and pears, and like them, produce pear- or apple-shaped pome fruits, which are bright golden yellow in color when mature. In most growing countries, quince are grown in small amounts; typically one or two quince trees are grown in a mixed orchard with several apple and other fruit trees (Westwood, 1993).

In Turkey, only a few molecular genetic studies have been conducted on quince to date (Dumanoglu et al., 2009; Bayazit et al., 2011). Moreover, no studies have previously considered molecular genetic characteristics of quince grown in the northeastern part of Turkey.

Polymerase chain reaction (PCR)-based molecular markers, including rapid amplified polymorphic DNA (RAPD) markers, have provided a powerful new tool for breeders to search for new sources of variation and to investigate genetic factors controlling quantitatively inherited traits. The molecular approach for identification of plant varieties/genotypes appears to be more effective than traditional morphological markers because it allows direct access to the hereditary material and makes it possible to understand relationships among plants (Williams et al., 1990; Paterson et al., 1991).

The aim of the present study was to assess genetic diversity within C. oblonga genotypes using RAPD markers and to compare the genotypes.

\section{MATERIAL AND METHODS}

Leaf samples from 14 C. oblonga genotypes were collected in the Coruh Valley, which is located in Northeast Anatolia in Turkey. The leaves were immediately stored at $-80^{\circ} \mathrm{C}$ for DNA extraction. Genomic DNA was extracted from powdered (ground in liquid nitrogen) leaf materials using a modification of methods described in Lin et al. (2001). Approximately 10-15 $\mathrm{mg}$ tissue from each plant sample was snap-frozen in liquid nitrogen in 2-mL Eppendorf tubes. A total volume of $1000 \mu \mathrm{L}$ DNA extraction buffer [100 mM Tris-HCl, $\mathrm{pH}$ 8.0, $50 \mathrm{mM}$ EDTA, $\mathrm{pH} 8.0,500 \mathrm{mM} \mathrm{NaCl}, 2 \%$ sodium dodecyl sulfate (w/v), $2 \% 2$-mercaptoethanol (v/v), and 1\% 
polyvinylpyrrolidone $(\mathrm{w} / \mathrm{v})]$ was added, and tubes were mixed well. The mixture was incubated at $65^{\circ} \mathrm{C}$ in a water bath for $40 \mathrm{~min}$ with intermittent shaking at 5-min intervals. The mixture was centrifuged at $12,000 \mathrm{~g}$ for $15 \mathrm{~min}$ at $4^{\circ} \mathrm{C}$. The supernatant was transferred to a clean $1.5-\mathrm{mL}$ tube, mixed with an equal volume of phenol:chloroform:isoamyl alcohol (25:24:1), and then centrifuged. The supernatant was collected and mixed with $1 / 10$ volume $10 \%$ CTAB-0.7 M $\mathrm{NaCl}$ in a clean tube. After centrifugation, the supernatant was collected and mixed gently with an equal volume of chloroform:isoamyl alcohol (24:1). DNA was precipitated by the addition of a 0.6 volume freezer-cold isopropanol for $10 \mathrm{~min}$ at $-20^{\circ} \mathrm{C}$. DNA was pelleted by centrifugation $(12,000 \mathrm{~g}, 10 \mathrm{~min})$ and the isopropanol was poured off; the recovered DNA was allowed to air-dry before being dissolved in $100 \mu \mathrm{L}$ Tris-borate-EDTA (TBE) buffer.

The samples were screened for RAPD variation using standard 10-base primers supplied by Operon. A 30- $\mu \mathrm{L}$ reaction cocktail was prepared as follows: $10 \mathrm{X} 3.0 \mu \mathrm{L}$ buffer, $1.2 \mu \mathrm{L} 10 \mathrm{mM}$ dNTPs, $1.2 \mu \mathrm{L} 25 \mathrm{mM}$ magnesium chloride, $2.0 \mu \mathrm{L} 5 \mu \mathrm{M}$ primer, $0.4 \mu \mathrm{L} 5 \mathrm{U}$ Taq polymerase, $19.2 \mu \mathrm{L}$ water, and $3.0 \mu \mathrm{L} 100 \mathrm{ng} / \mu \mathrm{L}$ sample DNA. A total of 10 RAPD primers, which were previously efficiently used in quince (Bayazit et al., 2011), were tested in this study (Table 1).

The thermocycler (Eppendorf Company) was programmed as follows: 2 min at $95^{\circ} \mathrm{C}$; 2 cycles of $30 \mathrm{~s}$ at $95^{\circ} \mathrm{C}, 1 \mathrm{~min}$ at $37^{\circ} \mathrm{C}, 2 \mathrm{~min}$ at $72^{\circ} \mathrm{C} ; 2$ cycles of $30 \mathrm{~s}$ at $95^{\circ} \mathrm{C}, 1 \mathrm{~min}$ at $35^{\circ} \mathrm{C}$, $2 \mathrm{~min}$ at $72^{\circ} \mathrm{C}$; 41 cycles of $30 \mathrm{~s}$ at $94^{\circ} \mathrm{C}, 1 \mathrm{~min}$ at $35^{\circ} \mathrm{C}, 2 \mathrm{~min}$ at $72^{\circ} \mathrm{C}$; followed by a final 5 -min extension at $72^{\circ} \mathrm{C}$, and then cooling down to $4^{\circ} \mathrm{C}$. The markers were checked twice for their reproducibility.

Twenty-seven microliters of the PCR products was mixed with $3 \mu \mathrm{L} 6 \mathrm{X}$ gel loading buffer, loaded on $1.5 \%$ agarose (w/v) gel in $0.5 \mathrm{X}$ TBE buffer, and electrophoresed at $70 \mathrm{~V}$ for $150 \mathrm{~min}$. The gel was stained in an ethidium bromide solution $(2 \mu \mathrm{L} / 100 \mathrm{~mL} 1 \mathrm{X}$ TBE buffer $)$ for $40 \mathrm{~min}$, and the bands were visualized under UV in a Bio Doc Image Analysis System with the UVisoft analysis package (Cambridge, UK).

The positions of scorable RAPD bands was transformed into a binary character matrix ( 1 for the presence and 0 for the absence of a band at a particular position), which was entered in the RAPDistance computer program (Armstrong et al., 1994). These data were used for the calculation of pairwise genetic distances between cultivars using the Jaccard coefficient (JC). The computer program calculated the degree of genetic dissimilarity between each pair of the 14 genotypes using Equation 1:

$$
\mathrm{JC}=1-a /(a+b+c)
$$

(Equation 1)

where $a$ is the number of bands shared by plant " $x$ " and plant " $y$ ", $b$ is the number of bands in plant " $x$ ", and $c$ is the number of bands in plant " $y$ ". The JC ignores the absence of matches. The distance matrix was used for cluster analysis using the unweighted pair-group method with arithmetic averages (UPGMA).

\section{RESULTS}

A total of 10 decamer oligonucleotide primers were used to investigate 14 quince genotypes. Results of the RAPD analysis are summarized in Table 1 . The 10 random primers generated a total of 53 RAPD bands. The highest number of polymorphisms (86\%) and the highest number of polymorphic bands were obtained from the OPA07 primer (Table 1). Primer OPA03 gave the lowest number of RAPD products (Table 1). 


\begin{tabular}{|c|c|c|c|c|}
\hline Primer code & Sequence $\left(5^{\prime} \rightarrow 3^{\prime}\right)$ & Number of total bands & Number of polymorphic bands & Polymorphism (\%) \\
\hline OPA-03 & AGTGAGCCAC & 7 & 2 & 29 \\
\hline OPA-05 & AGGGGTCTTG & 6 & 3 & 50 \\
\hline OPA-06 & GGTCCCTGAC & 5 & 4 & 80 \\
\hline OPA-07 & GAAACGGGTG & 7 & 6 & 86 \\
\hline OPA-09 & GGGTAACGCC & 5 & 2 & 40 \\
\hline OPA-10 & GTGATCGCAG & 5 & 2 & 40 \\
\hline OPA-11 & CAATCGCCGT & 7 & 3 & 43 \\
\hline OPA-16 & AGCCAGCGAA & 5 & 2 & 40 \\
\hline OPA-18 & AGGTGACCGT & 4 & 2 & 50 \\
\hline OPA-19 & CAAACGTCGG & 2 & 1 & 50 \\
\hline Total & & 53 & 27 & 51 \\
\hline
\end{tabular}

The distance matrix showed that the highest genetic similarity (0.96) was between the genotypes Kis 1 and Kis 2 and the lowest (0.42) was between Ekmek and Katirbasi. This indicates that the genotypes Kis 1 and Kis 2 are genetically closer to each other than any other genotypes. Similarly, the high genetic distance between Ekmek and Katirbasi indicates their potential for use in heterosis breeding practices. The average polymorphism among genotypes was $51 \%$, which shows clear and significant genetic diversity among the C. oblonga genotypes. Hence, these genotypes should be preserved as valuable genetic resources for breeding.

The dendrogram obtained from the RAPD markers grouped the 14 genotypes into two major clusters (Figure 1). Cluster 1 comprised three genotypes (Art 3, Katirbasi, and Katirbasi 1). Cluster 2 included the remaining 11 genotypes (Art 1, Art 2, Art 4, Art 5, Art 6, Art 7, Kis 1, Kis 2, Ecem, Anzavdere, and Ekmek). Cluster 2 was further divided into 4 subclusters. The first subcluster included Art 7, the second subcluster included Art 2 and Art 4, and the third subcluster included Art 5, Art 6, Kis 2, Kis 1, Art 1, Ecem, and Anzavdere. The fourth subcluster consisted of Ekmek alone (Figure 1).

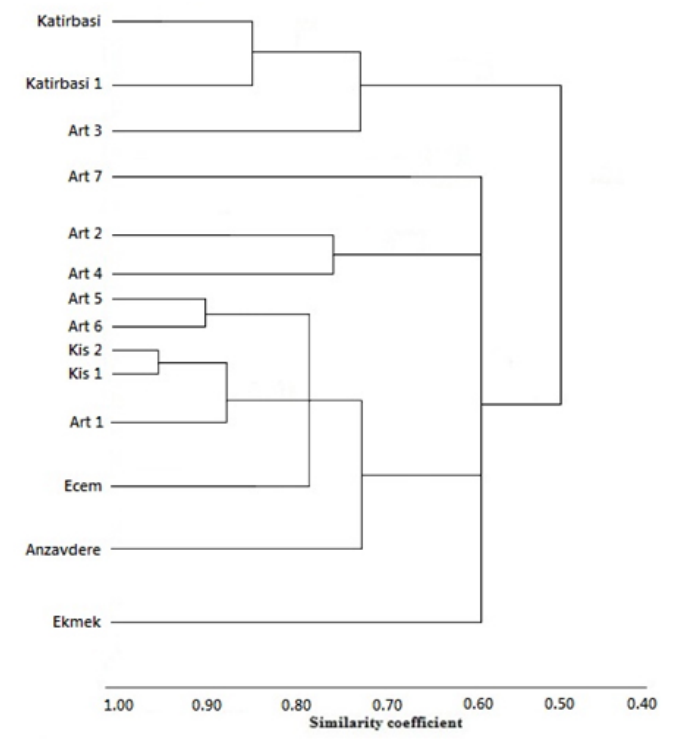

Figure 1. UPGMA dendrogram showing the relationship of Cydonia oblonga genotypes. 


\section{DISCUSSION}

The relatively high genetic distances among the 14 quince genotypes analyzed in this study clearly suggest genetically divergent parental origins, or a long history of adaptation to their respective micro-climatic regions. A previous study using the RAPD technique (Bayazit et al., 2011) revealed large genetic variations among different $C$. oblonga cultivars and genotypes grown in the western part of Turkey. The distinctness of the C. oblonga genotypes revealed by RAPD in the present study can be attributed to their unknown pedigree and high heterozygosity, which accompanied the long history of cultivation and domestication of this species. Classification of C. oblonga genotypes based on phenotypic variations or isozyme patterns should be reconsidered in light of results obtained from molecular analyses with RAPD markers. Molecular studies with RAPD have unraveled considerable differences among genotypes, as mentioned above. Thus, RAPD-based molecular markers can distinguish different genotypes that were previously indistinguishable using isozyme-based markers.

This study represents the first attempt to use molecular markers to investigate genetic relationships among C. oblonga genotypes grown under the same temperate agro-ecological conditions in the northeast region of Turkey. The genetic relationships determined with RAPD markers provide a more reliable method for identification of genotypes compared to morphological characters. Further investigations of the level and partitioning of genetic variation within genotypes would provide an important contribution for determining efficient quince management strategies.

\section{ACKNOWLEDGMENTS}

The authors thank the Ataturk University for supporting this study.

\section{REFERENCES}

Armstrong J, Gibbs A, Peakall R and Weiller G (1994). The RAPDistance Package. Available at [http://life.anu.edu.au/ molecular/software/rapd.htm]. Accessed July 12, 2013.

Asins MJ and Carbonell EA (1989). Distribution of genetic variability in a durum wheat world collection. Theor. Appl. Genet. 77: 287-294.

Bayazit S, Imrak B, Küden A and Güngör MK (2011). RAPD analysis of genetic relatedness among selected quince (Cydonia oblonga Mill.) accessions from different parts of Turkey. Hort. Sci. 38: 134-141.

Browicz K (1972). Cydonia Miller. In: Flora of Turkey and the East Aegean Islands (Davis PH, ed.). Edinburgh University Press, Edinburgh, 157.

Dumanoglu H, Gunes NT, Aygun A, San B, et al. (2009). Analysis of clonal variations in cultivated quince (Cydonia oblonga 'Kalecik') based on fruit characteristics and SSR markers. New Zealand J. Crop Hort. Sci. 37: 113-120.

Ercisli S (2004). A short review of the fruit germplasm resources of Turkey. Genet. Res. Crop Evol. 51: $419-435$.

FAO (2010). Agricultural Statistics, Food and Agricultural Organization of the United Nations. Available at [http: \\ww. faostat.fao.org]. Accessed November 1, 2012.

Kafkas S, Özgen M, Dogan Y, Özcan B, et al. (2008). Molecular characterization of mulberry accessions in Turkey by AFLP markers. J. Am. Soc. Hort. Sci. 133: 593-597.

Lin RC, Ding ZS, Li LB and Kuang TY (2001). A rapid and efficient DNA minipreparation suitable for screening transgenic plants. Plant Mol. Biol. Rep. 19: 379a-379e.

Paterson AH, Tanksley SD and Sorreis ME (1991). DNA markers in plant improvement. Adv. Agronomy 46: 39-90.

Westwood MN (1993). Temperate-Zone Pomology Physiology and Culture. 3rd edn. Timber Press Inc., Oregon.

Williams JG, Kubelik AR, Livak KJ, Rafalski JA, et al. (1990). DNA polymorphisms amplified by arbitrary primers are useful as genetic markers. Nucleic Acids Res. 18: 6531-6535. 